\title{
EFFECT OF FOOD-SIMULATING LIQUIDS ON MECHANICAL PROPERTIES AND SURFACE OF A DENTAL RESIN
}

\section{VPLIV SIMULIRANIH PREHRANSKIH TEKOČIN NA MEHANSKE LASTNOSTI IN POVRŠINO ZOBNEGA POLNILA}

\author{
Nassira Laissani ${ }^{1}$, Lakhdar Smata $^{2}$, Ferhat Djeddou ${ }^{3}$ \\ 1,2Setif1 University, Institut d'Optique et Mécanique de Précision, Physics and Mechanics of Metallic Materials Laboratory, 19000 Algeria \\ ${ }^{3}$ Setif1 University, Institut d'Optique et Mécanique de Précision, Applied Mechanics Laboratory, 19000 Algeria \\ smata_lakhdar@univ-setif.dz \\ Prejem rokopisa - received: 2018-03-18; sprejem za objavo - accepted for publication: 2018-06-14
}

doi:10.17222/mit.2018.047

\begin{abstract}
The purpose of this study was to evaluate the effects of food-simulating liquids on the mechanical properties and surface of a dental resin. The mechanical properties considered are fatigue and flexion. Samples $(n=108)$ were immersed into three liquids: distilled water, citric acid and heptane. The storage time was extended to four months. However, the specimens that were not broken after 10,000 shocks were subjected to flexion. The resulting histograms showed a weak increase in the flexion resistance. Moreover, a microscopic examination made with AFM indicated a modification of the surface morphology of the samples stored in distilled water for $90 \mathrm{~d}$. The citric acid presented undulations with peaks, whereas heptane had no effect compared with the intact resin.

Keywords: acrylic resin, storage, mechanical properties, food-simulating liquids
\end{abstract}

Namen študije je bil ovrednotenje vpliva simuliranih prehranskih tekočin na mehanske lastnosti in površino zobnega polnila. Mehanske lastnosti polnila so avtorji članka raziskovali z utrujanjem in upogibanjem. Vzorce $(\mathrm{n}=108)$ so potapljali v tri tekočine: destilirano vodo, citronsko kislino in heptan. Cas shranjevanja vzorcev v njih je bil do štiri mesece. Vzorce, ki se niso prelomili po 10.000 udarcih, so izpostavili še upogibanju. Dobljeni histogrami so pokazali rahlo izboljšanje odpornosti proti upogibanju. Mikroskopske preiskave z mikroskopom na atomsko silo (AFM; angl.: Atomic Force Microscopy) so pokazale spremembe površinske morfologije vzorcev, shranjenih v destilirani vodi za 90 dni. Hranjenje v citronski kislini je nakazalo valovito morfologijo površine $\mathrm{z}$ ostrimi vrhovi, medtem ko hranjenje $\mathrm{v}$ heptanu ni imelo vpliva na površino $\mathrm{v}$ primerjavi $\mathrm{z}$ nepoškodovanim polnilom.

Ključne besede: akrilna smola (zobno polnilo), hramba, mehanske lastnosti, simulacija prehranjevanja

\section{INTRODUCTION}

One of the most widely used dental materials is acrylic resin. Since its introduction in dentistry, it was widely employed for the confection of dental prosthesis ${ }^{1,2}$ due to its ease of manipulation, low cost, light weight, good aesthetic characteristics and biocompatibility.

Restorative materials used in dentistry are required to have long-term durability in the oral cavity. In different regions of the mouth, dentures are continuously bathed in a complex environment, particularly saliva, that contains substances such as water, proteins, amylases, etc. ${ }^{3}$ During eating and drinking, materials are also exposed to food components and beverages that consist of a variety of substances including proteins, lipids, carbohydrates, water and citric acids. In vitro, these products are simulated by suitable liquids.

Under clinical conditions, the mechanical strength of dental materials is normally characterized using static methods but fatigue tests are particularly well appropriated for the response of a material subjected to repeated loads such as chewing forces. ${ }^{4}$ The cyclic masticatory loading is an important mechanical load that can lead to a denture failure and thus decrease its lifetime. Therefore, the fatigue resistance is an ideal mechanical property for the study of the clinical lifetime of a denture.

The fracture of a denture is a rather common occurrence. After a period of service, it may be easily and accidentally fractured by biting a hard object or by an impact received when it is outside the mouth. ${ }^{5,6}$ Hence, a static force such as flexion, after a failure due to fatigue, reproduces this phenomenon well.

There are several researchers who have studied the mechanical properties of different dental materials after immersing them in food-simulating liquids. ${ }^{7-9}$ The majority of these works were mainly oriented on various dental composites. On the other hand, only few researches have focused on acrylic resins and apparently no study has been done on the effect of these liquids on the fatigue prior flexion. This study was consolidated by observing the surfaces of different samples with AFM after three months of storage where no investigation had been done on the surface states after any type of storage. However, explanations were given, describing the breaking mechanism of the biomaterial. 
In this context, the intent of this study was to evaluate the effects of three food-simulating liquids (distilled water, citric acid and heptane) used with an acrylic resin, on the mechanical properties, using fatigue and flexion. The immersion time was extended to four months. Therefore, the impact of these liquids on the biomaterial before and after the storage was studied by characterizing the surface morphologies.

\section{EXPERIMENTAL PART}

114 rectangular specimens $(2 \times 2 \times 25) \mathrm{mm}$ were prepared using a stainless steel mold. After hardening, the specimens were taken out of the mold. The controlled specimens $(n=6)$ were stored at room temperature in air. Others were randomly divided into three groups and then immersed at room temperature as follows: distilled water, $0.02 \mathrm{~N}$ citric acid, and heptane. The periods of storage time were $(15,30,45,60,90$ and 120) d.

The fatigue was determined using a device for cyclic loading with a shaft guided and ended with a spherical steel indenter at the center of a $4.0 \mathrm{~mm}$ diameter. Fatigue tests were run at $2 \mathrm{~Hz}$ until the completion of the $10^{4}$ cycles or the failure of the material. The samples that resisted $10^{4}$ shocks were subject to flexion. Flexural strength was determined using a three-point flexion test, performed in a universal testing machine (ZWICK ROWELL) at a crosshead speed of $0.5 \mathrm{~mm} / \mathrm{min}$. The values of the flexion strength were achieved using the software of the machine. To detect flaws in the material, cross-sections of the ruptured samples were examined using an optical microscope (Axiovert 40 MAT ZEISS).

The morphologies of the surfaces after storing the samples in various media for 90 days were observed with atomic force microscopy (Pacific Nanotechnology, Santa Clara, CALIFONIA, USA).

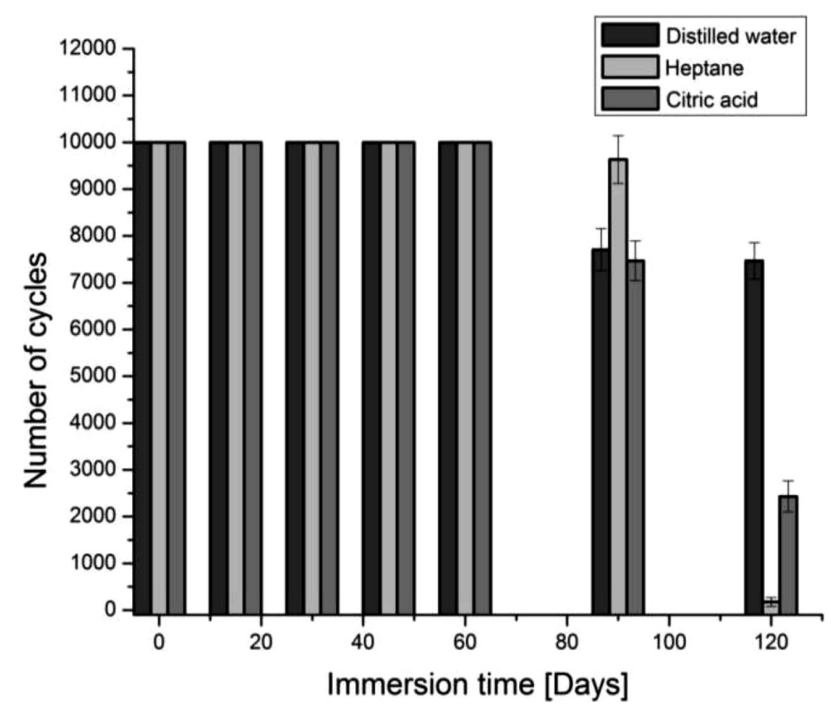

Figure 1: Mean number of cycles versus immersion time

\section{RESULTS}

The number of fatigue cycles is reported in Figure 1. The immersion of the samples in the three liquids provided constant values (10 000 cycles) of the fatigue up to the 60th day. After the 90th day, the fatigue was strongly decreased, in water to 7902 cycles and in acid storage to 7468 cycles, while the heptane storage caused a failure after 9634 cycles. At the end of the storage (120 d), in distilled water, the fatigue dropped to 7468 cycles, in acid to 2430 cycles and in heptane to 176 cycles.

The specimens which were not broken after 10000 shocks were subjected to the three-point flexion. The measurement of this resistance is reported in Figure 2. The histograms show a weak increase in the flexion résistance. The values of the flexion increased from 66.4 $\mathrm{MPa}$ to $69.2 \mathrm{MPa}$ for the storage in water and from 66.4 $\mathrm{MPa}$ to $72.0 \mathrm{MPa}$ for heptane, while the acid shows a noticeable growth (from 66.4 MPa to 74.2 MPa).

Images of the cross-sections of the broken samples, obtained with optical microcopy, are shown in Figure 3. Cracks that propagate from the porosities through the resins are visualized in theses figures. Microfissures are detectable due to the enlargement of the framed zones of the two micrographs. Other small porosities (A and B) are also visible in this figure.

On the other hand, a microscopic-examination result, compared to the resin without storage in Figure 4a, indicates a modification of the surface morphology of the samples stored in water for $90 \mathrm{~d}$ as shown in Figure $\mathbf{4 b}$. This texture is completely different from the other pieces. In Figure 4c, the citric acid presents undulations with peaks, whereas heptane from Figure 4d had no effect compared with dry resin.

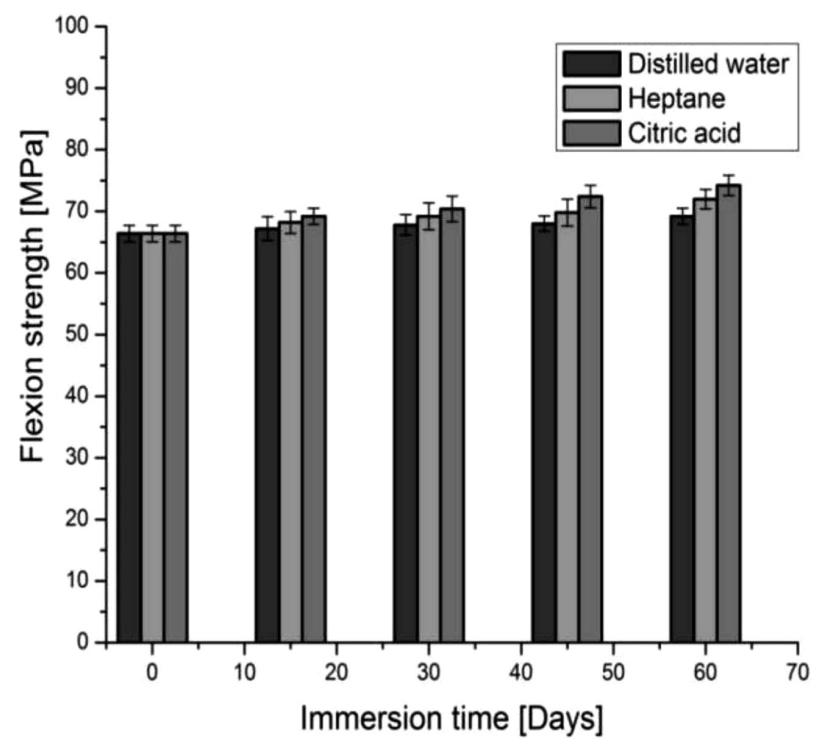

Figure 2: Mean flexion resistance versus immersion time 


\section{DISCUSSION}

There is a large variability in oral environments from one individual to another and at different times of the same day. In vitro, different conditions can be simulated by suitable liquids. Due to the diversity of environmental
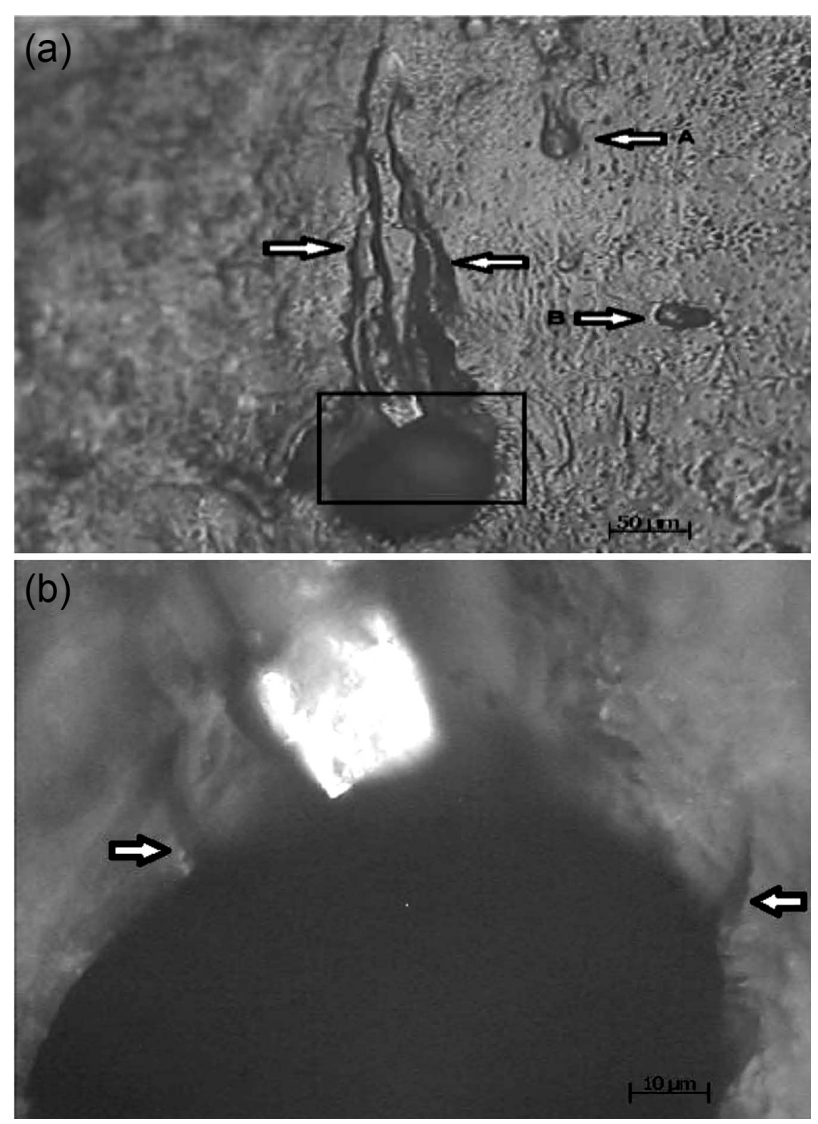

Figure 3: Optical-microscopy micrographs of the cross-sections of the broken resin samples: a) with cracks and small porosities (A and B), b) magnification of the framed area

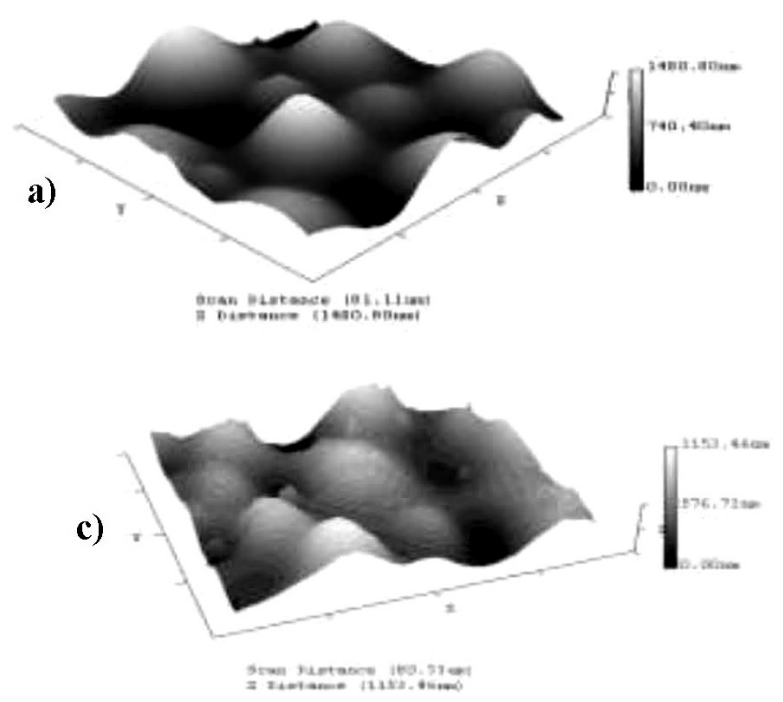

conditions, the oral and food-simulating liquids used for storing the specimens from this study were reduced primarily to distilled water, which substantially simulates natural saliva, and water as it is found in beverages or foods. On the other hand, citric acid represented juices and soft drinks as the product is part the composition of most of these beverages. Heptane substituted vegetable oils, butter and fatty meats. ${ }^{8,10}$

Restorative materials used in dentistry are required to have long-term durability in the oral cavity. In addition to the aqueous environment of the oral cavity, during eating, restorative materials are also subject to cyclic loading due to the repeated movements of chewing forces. ${ }^{11}$ Primarily, this cyclic masticatory force indicates that fatigue is responsible for the failure of dental restoration materials. ${ }^{12}$ Therefore, fatigue is one of the most important mechanical characteristics that needs to be considered when studying the long-term clinical performance of dental materials.

To evaluate the material resistance to fatigue, the specimens, after storage in the mediums, were mostly subjected to $10^{4}$ impact-load cycles or until a failure occurred. The frequency of the cycles was $2 \mathrm{~Hz}$. However, other test frequencies ranging from $0.3 \mathrm{~Hz}$ to 5 $\mathrm{Hz}^{13-16}$ were also used. These values varied in accordance with the type of fatigue, the materials and environmental conditions used. The number of the practiced load cycles of $10^{4}$ was set based on the previous studies. ${ }^{15-17}$ It was also estimated that the intraoral stress received by dental restorations during mastication is repeated more than $3 \times 10^{5}$ times per year. ${ }^{13}$ The number of loading cycles used in this study was low compared to the total number of load cycles that a restoration must withstand during its life service. However, some other works used cycles in the order of $10^{3}, 10^{5}$ and $10^{6}$, respectively. ${ }^{13,14,18}$ The measuring results of the fatigue showed two distinct stages: the first, which lasts up to

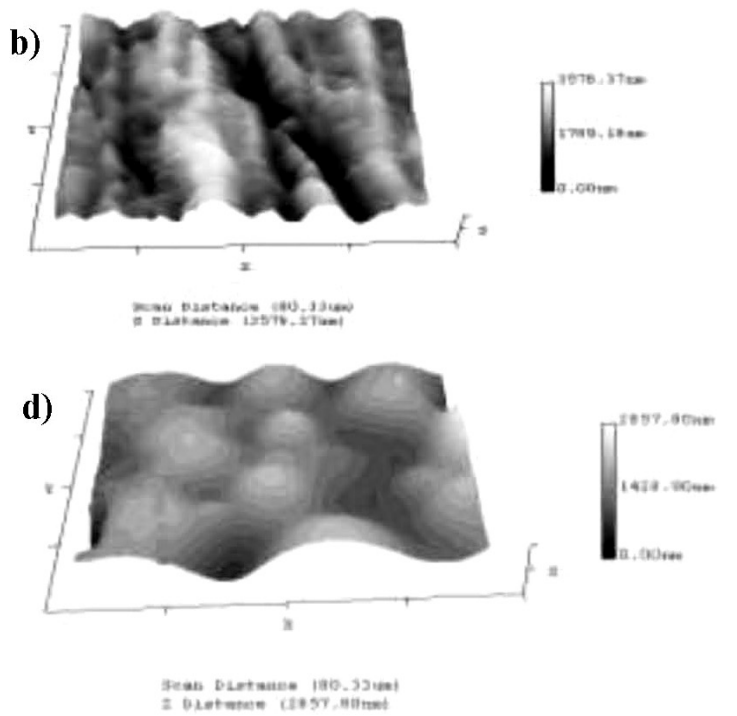

Figure 4: Atomic-force-microscopy images of the surfaces of acrylic-resin samples stored in: a) air, b) distilled water, c) citric acid, d) heptane 
$60 \mathrm{~d}$, is constant and the second is variable where a decrease in the fatigue resistance is observed. This behavior is characteristic of three storage environments. For the first period, one possible explanation indicates that the storage time is insufficient to see any change in the resistance to fatigue. It assumes that liquids do not have enough effect on the fatigue of the resin in the $10^{4}$ cycles imposed and that it takes more stress or more storage time to see a possibility for a material rupture. In this step, the flexural-strength test was used after the fatigue test to evaluate the mechanical properties of the previously "fatigued" materials.

In this study, the flexure resistance of acrylic resin was found to be increased after the immersion in the three simulating liquids. This behavior may be justified by the fact that the polymerization of the resin was incomplete. This phenomenon was reported in previous articles $^{16,19}$ where some residual monomer remained after polymerization..$^{20,21}$

It is well known that when a polymerization reaction is activated, the monomer converts into polymer chains and this reaction finishes when all the monomer is reacted. When more chains are formed due to the polymerization, there is less residual monomer and the material becomes more resistant. It should be noted that the monomers lower the mechanical properties of dental resins. ${ }^{21,22}$ After the immersion in water, two processes occur: plasticizer release and water absorption. Mainly, plasticizers provide the flexibility and softness of resins, ${ }^{23}$ which may contribute to the reduction of the mechanical properties. ${ }^{24,25}$ But the residual monomer acted as a plasticizer in the polymer structure,,$^{22,26}$ consequently leaching the residual monomer from the specimens and contributing to the increase in the flexion strength after the water storage. ${ }^{16,27}$ The water absorption of resin allows a release of unreacted components, principally monomers. ${ }^{25,28}$ The amount of the plasticizer that leached from the resin increased with the increasing immersion time, improving the strength of this material. However, the present study also took into account the effects of the other storage media (other than water) and the same phenomena applied to the other two liquids. It should be noted that the flexion-resistance variations are not important enough for dry resin and stored resins. Deterioration of the materials used for restorations often occurs gradually during a process of fatigue. This is illustrated in this work where the results of the second phase showed that the fracture strength under dry conditions was always higher than under wet conditions, in which the fatigue-fracture resistance of the acrylic resin after the immersion in the three liquids decreased with the storage time. Before the decrease in the resistance to fatigue, the samples resisted to the imposed $10^{4}$ cycles and the effects of the storage liquids appeared only after $60 \mathrm{~d}$ of immersion.

The failure due to the fatigue effort starts from a small structural defect such as a void or microcrack in the material, from which cracks are nucleated. Internal defects, such as air bubbles or porosities, can act as stress concentrators, contributing to the formation of microcracks under loading, thereby favoring a catastrophic failure ${ }^{6,17}$ Under the action of cyclic forces, cracks begin to form in the matrix and propagate, eventually causing a fast fracture. The latter phase is very short and the cyclic loading is able to drive the crack propagation, called a slow crack growth. ${ }^{14}$ However, the cracks continue to propagate and interconnect, eventually resulting in a catastrophic failure of the resin. ${ }^{17}$ An inherent fault or imperfection able to trigger an initiation of cracks occurs in composites during the fabrication, as well as restoration procedures. ${ }^{29}$ During the fabrication, air voids may be introduced when mixing the resin and when setting the paste in the mold; these pores are trapped inside the material due to the application of the pressing force to the upper part of the mold. However, other porosities resulting from the polymerization process may also be formed. ${ }^{30}$ The presence of these defaults persists even after the hardening of the materials.

The fissuring mechanism mentioned above is validated in Figure 3 where cracks initiated from the pores are observed. It should be noted that the propagation of cracks is due to the action of external excitations. However, in the present work, these are the cyclic loading and the flexion, which cause the breaking of the material. Figure $\mathbf{3 b}$ shows well the beginning of the formation of two microcracks, propagating from a defect. On the other hand, the small porosities shown in Figure 3a and $\mathbf{3 b}$ are not wide enough to have sufficient stress concentrations to create cracks.

Considering the effect of the leaching of monomers, the number of porosities is not important enough to undergo this failure mechanism before the 60th day of the immersion since no failure is produced due to the fatigue process. During this period, only flexion varies, as previously described, due to a lower residual monomer inside the material. Another aspect that must be considered is the fact that the residual monomer will also cause the formation of more porosities in the polymer matrix when removed from it. ${ }^{22}$ Therefore, when the level of residual monomer is high, the number of voids in the resin after leaching off the residual monomer will be high. This phenomenon is remarkable for long periods of storage and thus the number of porosities is more important, resulting in a decreased fatigue resistance after $60 \mathrm{~d}$ and $90 \mathrm{~d}$ of storage.

From the obtained values of the fatigue, we can say that time and exposure environment have effects on the intensification of the internal defects. Thus, with citric acid, the resin underwent a rapid degradation compared to those of distilled water and heptane. This shows a marking effect of citric acid on the resin compared to distilled water. For heptane, its effect appeared only after $90 \mathrm{~d}$ of immersion when a very rapid fall of resistance 
occurred. This medium was manifested better after $120 \mathrm{~d}$ of immersion when the resin was completely weakened.

In the present study, surface morphologies of the specimens were evaluated with AFM after 90 d of storage. The AFM micrographs revealed differences in the surface topography of the acrylic resin. This indicates a change in the surface texture of the investigated material caused by the immersion liquids compared with the resin without storage. This illustrates the effects of these two liquids on the surface of the biomaterial where a chemical reaction is produced between the antagonistic elements. These new factors participated in a sudden drop in the fatigue strength, in addition to the presence of the porosities within the samples, as it was previously described. These weaknesses occurred after $90 \mathrm{~d}$ of storage when the time and nature of the immersion liquids played a great role in reducing the fatigue of the biomaterial. This fact can be explained with the cavities caused by distilled water, which appear to provide an easy field for crack propagation while the peaks exhibited by the citric acid can be considered as the stress concentrators. On the other hand, heptane did not have a large effect on the surface of the resin where the original resin structure seems not to be changed. This resulted in a feeble decrease of the fatigue resistance caused by a relatively low porosity. However, 120-day storage seems to be the cause of the biomaterial's catastrophic failure. This can be explained with the fact that the immersion time allowed heptane to seep inside the material and ruin it.

According to this study, longer periods of food-simulating liquid storage are necessary to determine the durability of acrylic-resin restoration material. Under the buccal condition, this component can have a significant effect on the performance of this material, which may result in a reduction in the physico-mechanical properties. Hence, oral hygiene is necessary to increase the lifetime of this restoration material once it is placed in an oral environment.

\section{CONCLUSIONS}

The effects of the food-simulating liquids such as distilled water, citric acid and heptane on the mechanical properties and surface morphology of acrylic resin were studied. For the used liquids, results indicated that the fatigue resistance remained unchanged during the first $60 \mathrm{~d}$ of storage, whereas flexion increased in a progressive manner with the immersion time. After this period, a fatigue-strength drop was recorded after the cyclic loading where the resin was completely weakened by heptane at the end of the fatigue test.

The AFM micrographs indicated differences in the topography surface caused during the 90-day storage in distilled water and citric acid, while heptane did not have a significant effect.

\section{REFERENCES}

${ }^{1}$ B. Praveen, H. V. Babaji, B. G. Prasanna et al., Comparison of impact strength and fracture morphology of different heat cure denture acrylic resins: an in vitro study, J of Inter. Oral Health, 6 (2014), $12-16$

${ }^{2}$ T. Sekinishi, S. Inukai, N. Murakami, N. Wakayashi, Influence of denture tooth thickness on fracture mode of thin acrylic resin bases: An experimental and finite element analysis, J. Prosthet. Dent., 114 (2015), 122-129, doi:10.1016/j.prosdent.2014.11.011

${ }^{3}$ J. L. Ferracane, Hygroscopic and hydrolytic effects in dental polymer networks, Dent. Mater., 22 (2006), 211-222, doi:10.1016/j.dental. 2005.05.005

${ }^{4}$ E. C. Vouvoudi, I. D. Sideridou, Dynamic mechanical properties of dental nanofilled light-cured resin composites: Effect of food-simulating liquids, J. Mech. Behav. Biomed. Mater., 10 (2012), 87-96, doi:10.1016/j.jmbbm.2012.02.007

${ }^{5}$ N. M. Ajaj-Alkordi, M. H. Alssadi, Elastic modulus and flexural strength comparisons of high-impact and traditional denture base acrylic resins, Saudi Dent. J., 26 (2014), 15-18, doi:10.1016/ j.sdentj.2013.12.005

${ }^{6}$ E. Kelly, Fatigue failure in denture base polymers, J. Prost. Dent., (1969), 257-266, doi:10.1016/0022-3913(69)90289-3

${ }^{7}$ S. Y. Lee, E. H. Greener et al., Effect of food and oral simulating on dentine bond and composite strength, J. Dent., 22 (1994), 352-359, doi:10.1016/0300-5712(94)90088-4

${ }^{8}$ T. Akova, A. Ozkomur, H. Uysal, Effect of food-simulating liquids on the mechanical properties of provisional restorative materials, Dent. Mater., 22 (2006), 1130-1134, doi:10.1016/j.dental.2005. 09.009

${ }^{9}$ S. Y. Lee, E. H. Greneer, H. J. Muller, Effect of food and oral simulating fluids on structure of adhesive composite systems. J. Dent., 23 (1995), 27-35, doi:10.1016/0300-5712(95)90657-4

${ }^{10}$ I. D. Sideridou, E. C. Vouvoudi, E. A. Adamidou, Dynamic mechanical thermal properties of the dental light-cured nanohybrid composite Kalore, GC: Effect of various food/oral simulating liquids, Dent. Mater., 31 (2015), 154-161, doi:10.1016/j.dental.2014.11.008

${ }^{11}$ S. Grandini, C. Goracci, F. Moncesca, Fatigue resistance and structural characteristics of fiber post: three-point bending test and SEM evaluation, Dent. Mater, 21 (2005), 75-82, doi:10.1016/j.dental. 2004.02.012

${ }^{12}$ T. N. Gohring, L. Gallo, H. Luthy, Effect of water storage, thermocycling, the incorporation and site of placement of glass-fibers on the flexural strength of veneering composite, Dent. Mater., 21 (2005), 761-772, doi:10.1016/j.dental.2005.01.013

${ }^{13}$ S. Garoushi, L. V. J. Lassila et al., Static and fatigue compression test for particulate filler composite resin with fiber-reinforced composite substructure, Dent. Mater., 23 (2007), 17-23, doi:10.1016/j.dental. 2005.11.041

${ }^{14}$ U. Lohbauer, T. V. Horst et al., Flexural fatigue behavior of resin composite dental restoratives, Dent. Mater., 19 (2003), 435-440, doi:10.1016/S0109-5641(02)00088-X

${ }^{15}$ A. M. Diaz-Arnod, M. A. Vargas et al., Flexural and fatigue strengths of denture base resin, J. Prosthet. Dent., 100 (2008), 47-51, doi:10.1016/S0022-3913(08)60136-5

${ }^{16}$ J. M. Reis, C. E. Vergani et al., Effect of relining, water storage and cyclic loading on the flexural strength of a denture base acrylic resin, J. Dent., 34 (2006), 420-426, doi:10.1016/j.jdent.2005.10.001

${ }^{17}$ M. Braem, P. Lambrechts, G. Vanherle, Clinical relevance of laboratory fatigue studies, J. Dent., 22 (1994), 97-102, doi:10.1016/ 0300-5712(94)90010-8

${ }^{18} \mathrm{~S}$. Scherrer, A. H .Wiskott et al., Monotonic flexure and fatigue strength of composites for provisional and definitive restorations, J. Prosthet. Dent., 89 (2003), 579-88, doi:10.1016/S002239130 3001744

${ }^{19} \mathrm{~S}$. Klinge, G. Schmidt, R. Frankenbeger, Clinical behavior of solitaire: one-year results, J. Dent. Res., 97 (2000), 185-189 
${ }^{20}$ F. Key, I. Etikan, Evaluation of gloss changes of two denture acrylic resin materials in four different beverages, Dent. Mater., 20 (2004), 244-251, doi:10.1016/S0109-5641(03)00099-X

${ }^{21}$ E. Ruyter, C. Svendsen, Flexural properties of denture base polymers, J. Prosthet. Dent., 43 (1980), 95-104, doi:10.1016/00223913(80)90362-5

${ }^{22}$ A. D. Bek, N. N. Cevikt, A. Usanmaz, The effect of preparation conditions of acrylic denture base materials on the level of residual monomer, mechanical properties and water absorption, J. Dent, 23 (1995), 313-318, doi:10.1016/0300-5712(94)00002-W

${ }^{23}$ T. Kawahara, Y. Nomura et al., Leachability of plasticizer and residual monomer from commercial temporary restorative resins, J. Dent., 32 (2004), 277-283, doi:10.1016/j.jdent.2003.12.004

${ }^{24}$ P. F. Cesar, W. G. Miranda, Influence of shade and storage time on the flexural strength, flexural modulus, and hardness of composites used for indirect restorations, J. Prosthet. Dent., 86 (2001), 289-96, doi: $10.1067 / \mathrm{mpr} .2001 .114513$

${ }^{25}$ I. D. Sideridou, V. Tserki, G. Papanatasiou, Study of water sorption, solubility and modulus of elasticity of light-cured dimetha- crylate-based dental resins, Biomat., 24 (2003), 655-665, doi:10.1016/S0142-9612(02)00380-0

${ }^{26}$ L. V. J. Lassila, T. Nohrstrom, P. K. Vallittu, The influence of shortterm water storage on the flexural properties, Biomat., 23 (2002), 2221-2229, doi:10.1016/S0142-9612(01)00355-6

${ }^{27}$ J. Konchada, S. Karthigeyan et al., Effect of simulated microwave disinfection on the mechanical properties of three different types of denture base resins, J. Clinic Diagn. Res., 12 (2013), 3051-3053, doi:10.7860/JCDR/2013/7376.3850

${ }^{28}$ D. C. Watts, B. K. Kisumbi, G. Toworfe, Dimensional changes of resin/ionomer restoratives in aqueous and neutral media, Dent. Mater., 16 (2000), 89-96, doi:10.1016/S0109-5641(99)00098-6

${ }^{29}$ F. Takeshige, Y. Kawakami et al., Fatigue behavior of resin composites in aqueous environments, Dent. Mater., 23 (2007), 893-899, doi:10.1016/j.dental.2006.06.031

${ }^{30}$ C. Santos, L. Clarke et al., Water absorption characteristics of dental composites incorporating hydroxyapatite filler, Biomat., 23 (2002), 1897-1904, doi:10.1016/S0142-9612(01)00331-3 